\title{
EVALUATION OF PARTIAL ROOT ZONE DRYING IRRIGATION UNDER GATED PIPES SYSTEM FOR CORN CROP
}

\author{
Gomaa, A.H $^{(1)}$; A.A. Samak ${ }^{(1)}$; S. I. ELKhatib ${ }^{(2)}$; and H. M. Sharaf ${ }^{(2)}$
}

\section{ABSTRACT}

In recent time, Egypt is suffering from the scarcity of fresh water. In addition, Egypt is one of the event states under the water poverty line, who is identified as less than $1000 \mathrm{~m}^{3}$ per capita per year due to the existence of dry climatic conditions in most parts of the country and limited available water resources, therefore optimization and saving of water consumption have vital importance. The main goal of this research is to study the effect of Partial Root zone Drying (PRD) on corn yield, water distribution efficiency and water use efficiency compared with conventional irrigation (CI).Field experiment was conducted during summer season of 2017 in the Agricultural research station, Etay ElBaroud, El-Behera Governorate (Etay-El-Baroud region is $6 m$ above sea level, $30^{\circ} 88 / \mathrm{N}$ and $30^{\circ} 66 / \mathrm{E}$ ). Corn plants were planted under different irrigation regimes which were Alternate Partial Root zone Drying (APRD),Fixed Partial Root zone Drying (FPRD), and Conventional Irrigation (CI) comparing with control irrigation. The irrigation regimes were carried out under two levels of land leveling $(0.05 \%-0.1 \%)$, and three levels of water cutting times. The experimental treatments were irrigated by $152 \mathrm{~mm}$ diameter of PVC gated pipes system. The results indicated that, the APRD treatment achieved the highest value of corn production $\left(7.85 \mathrm{Mg} \mathrm{ha}^{-1}\right)$ when the applied water was reached to the end of furrow plus 5 minutes storage $\left(Q_{3}\right)$ under furrow slope of $0.1 \%$ and improving water use efficiency (WUE) when applied water was reached $5 \mathrm{~m}$ before the end of furrow length $\left(Q_{2}\right)$ by $1.73 \mathrm{~kg} \mathrm{~m}^{-3}$ under furrow slope of $0.1 \%$. Also, the APRD regime saved $37.16 \%$ of applied water under $Q_{2}$ and furrow slope of $0.1 \%$.

Key words: Gated Pipes System - Conventional Irrigation - Partial Root zone Drying-Corn Crop - Water Use Efficiency.

\footnotetext{
${ }^{(1)}$ Agricultural Engineering Department, Faculty of Agri., Menoufia University (2) Agricultural Engineering Institute, Agricultural Research Center (ARC).
} 


\section{INTRODUCTION}

$\mathrm{E}$ gypt has reached a state where the quantity of water available is imposing limits on its national economic development. Water shortage is the most important factor constraining agriculture production all over the world. In Egypt, agriculture consumes the largest amount of the available water with its share exceeding $85 \%$ of the total demand for water. So, the study is an attempt to find ways to solve the water scarcity problem. According to the Ministry of Water Resources and Irrigation, Egypt already uses $127 \%$ of its water resources meaning that Egypt imports $27 \%$ of its water used through imported food and other products and by 2020 Egypt could be using 147\% according to Waseem, (2017).Partial Root Zone Drying (PRD) is modified form of Deficit Irrigation (DI) that half of the root system is subject to drying soil and the other half is growing in irrigated soil in each irrigation event. Partial root zone drying is one of the deficit irrigation strategies designed to keep half of the root system in a drying state, while the other half of the root zone is irrigated. Then, the treatment is reversed, allowing the previously wellirrigated side of the root system to dry down addition to fully irrigating the previously dry side. Wang et al., (2012) indicated that, alternate partial root zone irrigation (APRD) is water saving irrigation techniques being intensively studied in many regions of the world on a wide range of crops. Partial root zone drying and regulated deficit irrigation techniques have proven the efficiency in improving the irrigation water use efficiency and fruit quality and dry fruit yield as compared with control irrigation (Mahmoud et al., 2019). Fixed Partial Root zone Drying (FPRD) is an irrigation technique where water is applied only from one side of the root system while the other part is exposed to continuous dry conditions. FPRD was used as a water saving irrigation strategy compared to Alternate Partial Root zone Drying (APRD) and conventional irrigation (Lekakis et al., (2011). Surface irrigation has a lower efficiency than other methods and it is the oldest most widely used irrigation method in Egypt and the world over. Irrigation water generally infiltrates into the root zone during conveyance and recession of water at the soil surface (Amer and Amer, 2010). Gated irrigation pipes system is an important tool for improving surface irrigation, its development depends on 
replacing the gates by designed self-compensating nozzle (AbdelRahman, 2010). Using of gated pipes system in surface irrigation helps to reduce water losses commonly associated with the use of the traditional furrows (El-Shafie, et al., 2017).In Egypt, Corn crop (Zea mays L.) is one of the most important cereal crops grown principally during the summer season. Great attention has been paid to increase total corn production(Osama and Ahmed, 2015). The main goal of this research is to study the effect of Partial Root zone Drying (PRD) on corn yield, water distribution efficiency and water use efficiency compared with conventional irrigation (CI).

\section{MATERIALS AND METHODS}

Field experiment was carried out during summer season of 2017 growing in the Agricultural research station, Etay El-Baroud, El-Behera Governorate. Soil located at an arid site in northern Egypt (Etay ElBaroud region is $6 \mathrm{~m}$ above sea level, $30^{\circ} 88 / \mathrm{N}$ and $30^{\circ} 66 / \mathrm{E}$ ). Two levels of field leveling were selected as plots design which were $0.05 \%$ leveling as the first plot and $0.1 \%$ leveling as the second plot. Each furrow had $0.75 \mathrm{~m}$ wide and $45 \mathrm{~m}$ long. Some physical and mechanical analysis of the soil was determined according to Black et al., (1965).The soil samples were collected upto $60 \mathrm{~cm}$ soil depth to determine soil mechanical analysis, field capacity, permanent wilting point, density and organic matter for each soil depth and the results presented in Table (1).

Table (1): Soil mechanical analysis of the experimental site

\begin{tabular}{|c|c|c|c|c|c|c|c|c|}
\hline \multirow{2}{*}{ 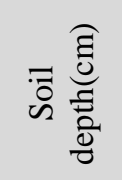 } & \multicolumn{4}{|c|}{ Particle size distribution, $\%$} & \multirow{2}{*}{ 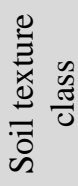 } & \multirow{2}{*}{$\begin{array}{c}\text { Field } \\
\text { Capacity } \\
(\%)\end{array}$} & \multirow{2}{*}{$\begin{array}{c}\text { Wilting } \\
\text { Point } \\
(\%)\end{array}$} & \multirow{2}{*}{$\begin{array}{c}\text { Bulk } \\
\text { density } \\
\left(\mathrm{g}, \mathrm{cm}^{-3}\right)\end{array}$} \\
\hline & $\begin{array}{c}\text { Sand } \\
\text { Coarse }\end{array}$ & $\begin{array}{l}\text { Sand } \\
\text { Fine }\end{array}$ & Silt & Clay & & & & \\
\hline $0-15$ & 4.67 & 15.96 & 17.53 & 61.84 & \multirow{4}{*}{ Clay } & 37.8 & 18.6 & 1.11 \\
\hline $15-30$ & 4.50 & 14.00 & 17.50 & 64.50 & & 34.2 & 16.2 & 1.09 \\
\hline $30-45$ & 4.40 & 14.50 & 17.60 & 63.50 & & 33.1 & 15.5 & 1.24 \\
\hline $45-60$ & 3.00 & 16.00 & 16.00 & 65.00 & & 30.6 & 14.7 & 1.34 \\
\hline
\end{tabular}

Soil moisture content $\left(\mathrm{M}_{\mathrm{c}}\right)$ was calculated by using the following equation according to Casillas, (1978): 


$$
M_{c}=\frac{M_{w}-M_{d}}{M_{d}} \times 100
$$

Where: $\mathrm{M}_{\mathrm{C}}$ is the soil moisture content (dry weight basis) $\%, \mathrm{M}_{\mathrm{W}}$ is the wet weight of soil (gm), and $M_{\mathrm{d}}$ is the dry weight of soil (gm).

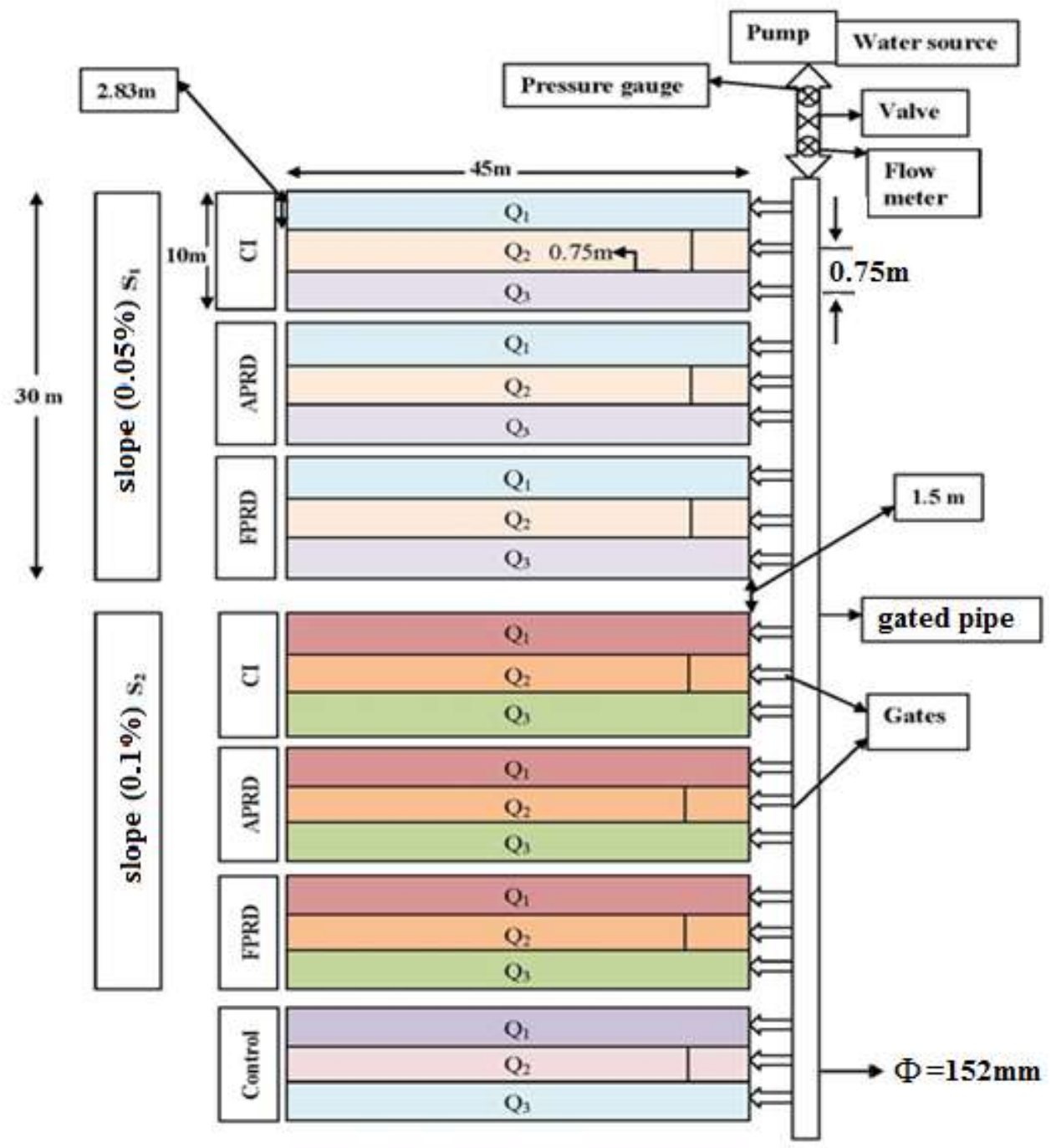

Fig. (1): schematic diagram of the experimental set up and arrangements of treatments.

$\mathbf{C I}=$ Conventional irrigation

APRD = Alternate partial root zone drying irrigation

FPRD $=$ Fixed partial root zone drying irrigation $\mathbf{S}=$ Laser leveling $\quad\left(\mathbf{S}_{\mathbf{1}}=0.05 \%\right.$ and $\left.\mathbf{S}_{\mathbf{2}}=0.10 \%\right)$

$\mathbf{Q}_{\mathbf{1}}=$ Apply water to the end of furrow $\quad \mathbf{Q}_{\mathbf{2}}=$ Apply water $5 \mathrm{~m}$ before the end of furrow

$\mathbf{Q}_{3}=$ Apply water to the end of furrow with 5 min storage 
Field experiment was concerned with three factors which can be described as follows: Two levels of soil leveling were used which were $0.05 \%$ and $0.1 \%$, three levels of water cutting time which were $\left(\mathrm{Q}_{1}\right)$ water cutting when reached to the end of furrow, $\left(\mathrm{Q}_{2}\right)$ water cutting when reached to $5 \mathrm{~m}$ before the end of furrow, and $\left(\mathrm{Q}_{3}\right)$ water cutting when reached to the end of furrow with 5 minutes storage. Also, the tested irrigation regimes were conventional irrigation (CI), alternate partial root zone drying irrigation (APRD), and fixed partial root zone drying irrigation (FPRD). Two levels of field leveling were selected as plots design $0.05 \%$ leveling as the first plot and $0.1 \%$ leveling as the second plot. In every experimental plot there were three subplots, every subplot with $10 \mathrm{~m}$ width and $45 \mathrm{~m}$ length, included 9 furrows; each three furrows were considered as one specified treatment. Each furrow had $0.75 \mathrm{~m}$ wide and $45 \mathrm{~m}$ long. The site description of the experimental field is as shown in Fig. (1).

Water distribution efficiency (DU) was calculated according to James (1988) as follows:

$$
D U=\frac{Y}{(1-d r)} \times 100
$$

Where: DU is distribution uniformity $(\%), d_{r}$ is the average depth of soil water stored along the run during the irrigation $(\mathrm{cm})$, and $\mathrm{Y}$ is the average stantard deviation from $\mathrm{d}_{\mathrm{r}}(\mathrm{cm})$.

Water application efficiency $\left(E_{a}\right)$ was estimated using the following equation of Brouwer et al., (1985)

$$
E_{a}=\frac{w_{a v}}{w_{a}} * 100
$$

Where: $\mathrm{E}_{\mathrm{a}}$ is water application efficiency, $\%, \mathrm{~W}_{\mathrm{av}}$ is volume of water stored per hectar in root zone during the irrigation, $\mathrm{m}^{3} \mathrm{ha}^{-1}$, and $\mathrm{W}_{\mathrm{a}}$ is volume of water delivered to the farm per hectar, $\mathrm{m}^{3} \mathrm{ha}^{-1}$.

The water use efficiency (WUE) as a measure to clarify variation in yield due to irrigation water was calculated according to Michael (1978) as following:

$$
W U E\left(\mathrm{~kg} \mathrm{~m}^{-3}\right)=\frac{Y_{i}}{W_{a}}
$$

Where: WUE is water use efficiency, $\left(\mathrm{kg} \mathrm{m}^{-3}\right), \mathrm{Y}_{\mathrm{i}}$ is yield, $\left(\mathrm{Mg} \mathrm{ha}^{-1}\right)$ and $\mathrm{W}_{\mathrm{a}}$ is the seasonal total applied water, $\left(\mathrm{m}^{3} \mathrm{ha}^{-1}\right)$. 
The obtained data were analyzed using the Statistical Analysis System Software (Costat, V6.4). Two ways analysis of variance was used.

\section{RESULTS AND DISCUSSION}

\subsection{Water advance, water recession time, and infiltrated depth}

The results showed that, water advance time, water recession time and infiltrated depth were affected by furrow slope as shown in Fig. (2). It was obvious that, increasing slope from $0.05 \%$ to $0.1 \%$, water advance time decreased, recession times about water infiltrated depth was increased. The reported results are in agreement with results found by Eltantawy et al. (2006).

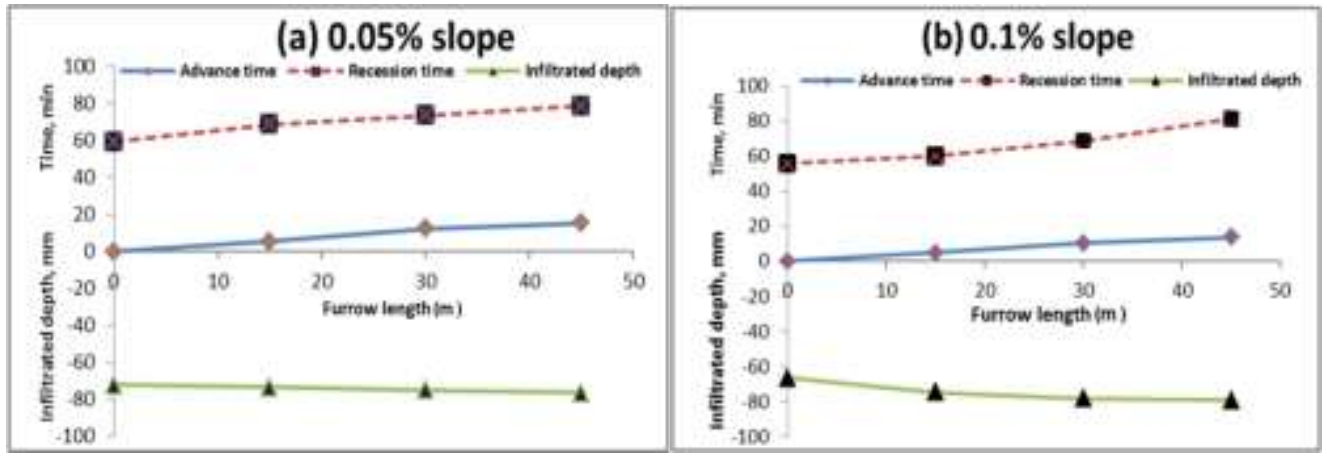

Fig. (2): Water advance time, water recession time and infiltrated depth of APRD treatment under $\mathrm{Q}_{1}$ of water application for (a) $0.05 \%$ and (b) $0.1 \%$ of furrow slope.

Fig. (2). illustrated the results of APRD at water application of $\mathrm{Q}_{1}$ treatments, the total water advance times were $15.4 \mathrm{~min}$ and $13.6 \mathrm{~min}$ at furrow slopes of $0.05 \%$ and $0.1 \%$, respectively (decreased by $11.69 \%$ ). On the other hand, total recession time were $78.6 \mathrm{~min}$ and $81.4 \mathrm{~min}$ at furrow slopes of $0.05 \%$ and $0.1 \%$, respectively (increased by $3.56 \%$ ). The maximum infiltrated depths were $76.5 \mathrm{~mm}$ and $79.3 \mathrm{~mm}$ at furrow slopes of $0.05 \%$ and $0.1 \%$, respectively (increased by $3.66 \%$ ) under $\mathrm{Q}_{1}$ treatment where the water cutting was occurred when the water reached to the end of furrow length.

The results showed that, the total water advance times were $16.5 \mathrm{~min}$ and $12.2 \mathrm{~min}$ at furrow slopes of $0.05 \%$ and $0.1 \%$, respectively (decreased by $26.1 \%$ ). Meanwhile, the total recession time were $82 \mathrm{~min}$ and $83.2 \mathrm{~min}$ at furrow slopes of $0.05 \%$ and $0.1 \%$, respectively (increased by $1.46 \%$ ). The 
maximum water infiltrated depths were $74.4 \mathrm{~mm}$ and $76.9 \mathrm{~mm}$ at furrow slopes of $0.05 \%$ and $0.1 \%$, respectively (increased by $3.36 \%$ ). These results are in agreement with the results reported by Abd El-Rahman (1985).
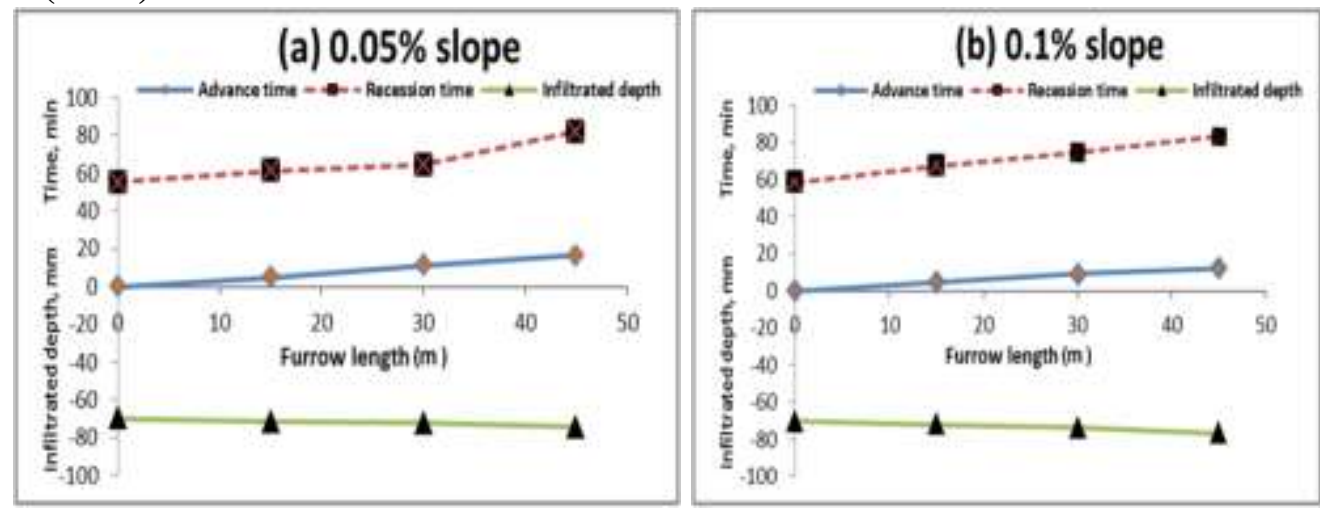

Fig.(3): Water advance time, water recession time and infiltrated depth of CI treatment at $\mathrm{Q}_{1}$ of water application for (a) $0.05 \%$ and (b) $0.1 \%$ of furrow slope.

\subsection{Corn yield parameters}

The relationship between the effect of water amount and irrigation regime under furrow slope of $0.05 \%$ and $0.1 \%$ on corn yield under different three water application treatments $\left(\mathrm{Q}_{1}, \mathrm{Q}_{2}\right.$ and $\left.\mathrm{Q}_{3}\right)$ are shown in Table (2). It showed that, under all of water amount there were high significant differences between treatments, where there were significant differences between APRD, FPRD and CI in $\mathrm{Q}_{1}$ at furrow slope of $0.05 \%$, while at furrow slope of $0.1 \%$ there were high significant differences between APRD, FPRD and $\mathrm{CI}$ in $\mathrm{Q}_{1}$. Also, there were significant differences between APRD, FPRD and CI in $\mathrm{Q}_{2}$ at furrow slope of $0.05 \%$ and $0.1 \%$; also, there were high significant differences between APRD, FPRD and $\mathrm{CI}$ in $\mathrm{Q}_{3}$. For corn yield, it was noticed that, there were significant differences between treatments, where there were significant differences between APRD, FPRD and CI in $\mathrm{Q}_{1}$ at furrow slope of $0.05 \%$, while at furrow slope of $0.1 \%$ there were high significant differences between APRD, FPRD and CI in $\mathrm{Q}_{1}$. In addition, there were significant differences between APRD, FPRD and CI in $\mathrm{Q}_{2}$ andQ ${ }_{3}$ at furrow slope of $0.05 \%$ and $0.1 \%$. Moreover, it can be noticed that, the corn yield under APRD treatment was the highest $\left(7.85 \mathrm{Mg} \mathrm{ha}^{-1}\right)$ under the water application of 
$\mathrm{Q}_{3}$ comparing with the other treatments of $\mathrm{Q}_{1}$ and $\mathrm{Q}_{2}$. It increased by about $9.68 \%$ and $18.5 \%$, respectively under furrow slope of $0.1 \%$. The same results were reported by Consoli et al., (2017).

Table (2): Seasonal water applied and corn yield under the different irrigation treatments

\begin{tabular}{|c|c|c|c|c|c|c|c|}
\hline \multirow{2}{*}{$\begin{array}{l}\text { Slope of } \\
\text { furrow }\end{array}$} & \multirow{2}{*}{$\begin{array}{l}\text { Irrigation } \\
\text { regime }\end{array}$} & \multicolumn{3}{|c|}{ Seasonal water applied $\left(\mathrm{m}^{3} \mathrm{ha}^{-1}\right)$} & \multicolumn{3}{|c|}{ Corn yield $\left(\mathrm{Mg} \mathrm{ha}^{-1}\right)$} \\
\hline & & $\mathrm{Q}_{1}$ & $\mathrm{Q}_{2}$ & $\mathrm{Q}_{3}$ & $\mathrm{Q}_{1}$ & $\mathrm{Q}_{2}$ & $\mathrm{Q}_{3}$ \\
\hline & Control & $7735.0^{\mathrm{a}}$ & $7358.9^{\mathrm{a}}$ & $8032.5^{\mathrm{a}}$ & $5.59^{d}$ & $3.76^{\mathrm{d}}$ & $6.06^{d}$ \\
\hline \multirow{3}{*}{$\stackrel{n}{0} 0^{\circ}$} & APRD & $5698.2^{\mathrm{c}}$ & $5155.1^{\mathrm{d}}$ & $5873.8^{\mathrm{d}}$ & $6.97^{\mathrm{a}}$ & $6.62^{\mathrm{a}}$ & $7.71^{\mathrm{a}}$ \\
\hline & FPRD & $5597.8^{\mathrm{d}}$ & $5331.2^{\mathrm{c}}$ & $6016.6^{\mathrm{c}}$ & $6.18^{\mathrm{c}}$ & $5.41^{\mathrm{c}}$ & $6.31^{\mathrm{c}}$ \\
\hline & $\mathrm{CI}$ & $5895.3^{b}$ & $5597.8^{b}$ & $6176.1^{b}$ & $6.83^{b}$ & $6.26^{\mathrm{b}}$ & $7.35^{b}$ \\
\hline $\mathrm{LSD}=0.05$ & & 51.07 & 48.342 & 40.150 & 0.036 & 0.027 & 0.052 \\
\hline \multirow{3}{*}{$\frac{0}{0}$} & APRD & $5031.3^{\mathrm{d}}$ & $4629.1^{\mathrm{d}}$ & $5416.8^{\mathrm{d}}$ & $7.09^{\mathrm{a}}$ & $6.40^{\mathrm{a}}$ & $7.85^{\mathrm{a}}$ \\
\hline & FPRD & $5176.5^{\mathrm{c}}$ & $4867.1^{c}$ & $5585.9^{c}$ & $6.14^{\mathrm{c}}$ & $4.71^{\mathrm{c}}$ & $5.47^{\mathrm{c}}$ \\
\hline & CI & $5383.6^{b}$ & $5207.4^{b}$ & $5659.6^{b}$ & $6.90^{b}$ & $6.33^{b}$ & $7.40^{b}$ \\
\hline $\mathrm{LSD}=0.05$ & & 50.155 & 38.821 & 41.190 & 0.074 & 0.114 & 0.114 \\
\hline
\end{tabular}

Table (3) showed, the effect of total seasonal water applied and irrigation regime on physical characteristics of corn crop (weight of 100 grains (g) number of grains per row and plant height $(\mathrm{cm})$. It was noticed that, weight of 100 grains $(\mathrm{g})$ under control treatment had a high value inQ $_{2}$ (33.6 g) and low value in $\mathrm{Q}_{3}(31.5 \mathrm{~g})$.

Table (3): Physical characteristics for all the studied experimental treatments

\begin{tabular}{|c|c|c|c|c|c|c|c|c|c|c|}
\hline \multirow{2}{*}{$\begin{array}{l}\text { Slope } \\
\text { of } \\
\text { furrow }\end{array}$} & \multirow{2}{*}{$\begin{array}{l}\text { Irrigation } \\
\text { regime }\end{array}$} & \multicolumn{3}{|c|}{$\begin{array}{l}\text { Weight of } 100 \text { grain } \\
(\mathrm{g})\end{array}$} & \multicolumn{3}{|c|}{$\begin{array}{c}\text { Number of grains per } \\
\text { row }\end{array}$} & \multicolumn{3}{|c|}{$\begin{array}{l}\text { Plant height } \\
(\mathrm{cm})\end{array}$} \\
\hline & & $\mathrm{Q}_{1}$ & $\mathrm{Q}_{2}$ & $\mathrm{Q}_{3}$ & $\mathrm{Q}_{1}$ & $\mathrm{Q}_{2}$ & $\mathrm{Q}_{3}$ & $\mathrm{Q}_{1}$ & $\mathrm{Q}_{2}$ & $\mathrm{Q}_{3}$ \\
\hline \multirow{4}{*}{$\stackrel{n}{0}$} & & $32.7^{\mathrm{c}}$ & $33.6^{\mathrm{c}}$ & $31.5^{\mathrm{d}}$ & $37.5^{\mathrm{c}}$ & $34.6^{\mathrm{d}}$ & $39.2^{\mathrm{d}}$ & $327.2^{\mathrm{a}}$ & $321.5^{\mathrm{a}}$ & $335.4^{\mathrm{a}}$ \\
\hline & & $35.9^{\mathrm{a}}$ & $38.6^{\mathrm{a}}$ & $33.9^{\mathrm{a}}$ & $42^{\mathrm{b}}$ & $46.1^{\mathrm{a}}$ & $45^{\mathrm{b}}$ & $.7^{\mathrm{d}}$ & $306.5^{\mathrm{d}}$ & $20.8^{\mathrm{c}}$ \\
\hline & FPRD & $34.9^{6}$ & $36.3^{b}$ & $32.8^{\mathrm{c}}$ & $46^{\mathrm{a}}$ & $43^{b}$ & $46.5^{\mathrm{a}}$ & $322.6^{b}$ & $307.1^{\mathrm{c}}$ & $312.5^{d}$ \\
\hline & CII & $30.8^{\mathrm{d}}$ & $31.5^{\mathrm{d}}$ & $33.8^{b}$ & $38^{\mathrm{d}}$ & $41.2^{\mathrm{c}}$ & $42.5^{\mathrm{c}}$ & $318.5^{\mathrm{c}}$ & $316.8^{b}$ & $326.4^{b}$ \\
\hline \multirow{5}{*}{$\overrightarrow{0}$} & $\mathrm{ICD}$ & 0.142 & 0.071 & & $\overline{0.074}$ & 0.167 & & & 0.741 & 0.590 \\
\hline & & $34.8^{b}$ & $36.7^{\mathrm{a}}$ & 37 & $43.4^{b}$ & $44.7^{\mathrm{a}}$ & $44.8^{b}$ & $305.1^{\mathrm{d}}$ & $302.3^{\mathrm{c}}$ & $18.6^{\mathrm{c}}$ \\
\hline & & $35.9^{\mathrm{a}}$ & $36.1^{\mathrm{b}}$ & & $47^{\mathrm{a}}$ & $42^{c}$ & $48^{\mathrm{a}}$ & $.5^{\mathrm{c}}$ & $302^{\mathrm{d}}$ & \\
\hline & & $35.9^{\mathrm{a}}$ & $33.5^{\mathrm{d}}$ & $36.2^{\mathrm{b}}$ & $42^{\mathrm{d}}$ & $43^{b}$ & 44 & $312.5^{b}$ & $308.6^{b}$ & $319.4^{b}$ \\
\hline & $\mathrm{SD}=0.05$ & 0.084 & 0.131 & 0.239 & 0.119 & 17 & $x y$ & 0.150 & 0.464 & 0.129 \\
\hline
\end{tabular}

Under furrow slope of $0.05 \%$, the APRD and FPRD achieved the highest values in weight of 100 grains $(\mathrm{g})$ under $\mathrm{Q}_{2}$ treatment; it was recorded about $(38.6 \mathrm{~g})$ and $(35.9 \mathrm{~g})$, respectively. Meanwhile, the CI treatment achieved the highest value of 100 -grains weight $(\mathrm{g})$ under $\mathrm{Q}_{3}$ treatment, which was recorded(33.8 g).Under furrow slope of $0.1 \%$, the APRD 
resulted in highest value in $\mathrm{Q}_{3}\left(37.2 \mathrm{~g}\right.$ ).Also, in FPRD the $\mathrm{Q}_{2}$ achieved high value (36.1g). Meanwhile, under $\mathrm{CI}$ treatment, the $\mathrm{Q}_{3}$ achieved high value $(36.2 \mathrm{~g})$. On the other hand, there were significant differences between treatments, where there were significant differences between APRD, FPRD and CI in $\mathrm{Q}_{1}$ under furrow slope of $0.05 \%$, while under furrow slope of $0.1 \%$ there were high significant differences between APRD, FPRD and CI in $\mathrm{Q}_{1}$. Also, there were significant differences between APRD, FPRD and CI in $\mathrm{Q}_{2}$ and $\mathrm{Q}_{3}$ under furrow slope of $0.05 \%$ and $0.1 \%$ for 100 -grainsweight. The results showed also that, the number of grains per row under the control treatment recorded high value with $\mathrm{Q}_{3}$ (39 grains per row); while with APRD irrigation regime, $\mathrm{Q}_{2}$ treatment result in a high value (46 grains per row). At FPRD treatment the $\mathrm{Q}_{3}$ achieved the highest value (about 46). Also, under CI treatment, the $\mathrm{Q}_{3}$ resulted in high value (42 grains per row). Meanwhile under furrow slope of $0.1 \%$, the APRD resulted a high value in $\mathrm{Q}_{3}$ (44 grains per row). At FPRD treatment the $\mathrm{Q}_{3}$ achieved high value (48 grains per row). Also, at CI treatment the $\mathrm{Q}_{3}$ resulted high value (44 grains per row). It was noticed that, there were significant differences between treatments $\mathrm{Q}_{1}, \mathrm{Q}_{2}$ and $\mathrm{Q}_{3}$ under furrow slope of $0.05 \%$ and $0.1 \%$ for number of grains per row. However, there were high significant differences between irrigation regimes (APRD, FPRD and CI) in $\mathrm{Q}_{1}, \mathrm{Q}_{2}$ and $\mathrm{Q}_{3}$ under furrow slope of $0.05 \%$ and $0.1 \%$ for plant height. The same results were reported by Han and Kang (2002).

\subsection{Water distribution efficiency, water application efficiency, and water use efficiency}

Results in Table (4) showed that, the value of water application efficiency was the greatest value with FPRD $\left(\mathrm{Q}_{1}\right) 75.9 \%$ under furrow slope of $0.05 \%$ compared with APRD and CI. While under furrow slope of $0.1 \%$, the APRD resulted in the highest value compared with FPRD and CI treatments where it was $85.2 \%$. However, under applied water of $\left(\mathrm{Q}_{2}\right)$, the control treatment resulted in the lowest value for water application efficiency $(51.8 \%)$ compared with other treatments. Under furrow slope of $0.05 \%$, the FPRD achieved the highest value (80.1\%) compared with APRD and CI. While under furrow slope of $0.1 \%$, the CI recorded the highest value (85.8\%) compared with APRD and FPRD treatments. 
Table (4): Water distribution efficiency, water application efficiency, water use efficiency and water saving percent

\begin{tabular}{|c|c|c|c|c|c|c|c|c|c|c|c|c|c|}
\hline \multirow[t]{2}{*}{$\begin{array}{c}\text { Furrow } \\
\text { slope }\end{array}$} & \multirow[t]{2}{*}{$\begin{array}{l}\text { Irrigation } \\
\text { regime }\end{array}$} & \multicolumn{3}{|c|}{$\begin{array}{c}\text { Water distribution } \\
\text { efficiency, }(\%)\end{array}$} & \multicolumn{3}{|c|}{$\begin{array}{l}\text { Water application } \\
\text { efficiency, }(\%)\end{array}$} & \multicolumn{3}{|c|}{$\begin{array}{l}\text { Water use } \\
\text { efficiency, } \\
\left(\mathrm{kg} \mathrm{m}^{-3}\right)\end{array}$} & \multicolumn{3}{|c|}{ Water saving, (\%) } \\
\hline & & $\mathrm{Q}_{1}$ & $\mathrm{Q}_{2}$ & $\mathrm{Q}_{3}$ & $\mathrm{Q}_{1}$ & $\mathrm{Q}_{2}$ & $\mathrm{Q}_{3}$ & $\mathrm{Q}_{1}$ & $\mathrm{Q}_{2}$ & $\mathrm{Q}_{3}$ & $\mathrm{Q}_{1}$ & $\mathrm{Q}_{2}$ & $\mathrm{Q}_{3}$ \\
\hline & Control & 85.5 & 84.8 & 81.3 & 48.5 & 51.8 & 49.5 & 0.87 & 0.91 & 0.82 & - & - & - \\
\hline \multirow{3}{*}{$\begin{array}{l}0 \\
2 \\
0 \\
0\end{array}$} & APRD & 89.1 & 89.1 & 89.8 & 74.9 & 79.1 & 73.0 & 1.32 & 1.53 & 1.29 & 27.1 & 30.0 & 26.9 \\
\hline & FPRD & 89.4 & 89.7 & 88.4 & 75.9 & 80.1 & 73.9 & 1.35 & 1.41 & 1.22 & 27.6 & 27.6 & 24.1 \\
\hline & CI & 80.6 & 82.6 & 84.6 & 73.2 & 71.3 & 70.1 & 1.12 & 1.19 & 1.16 & 23.8 & 24.0 & 23.1 \\
\hline \multirow{3}{*}{$\frac{0}{0}$} & APRD & 89.7 & 90.2 & 89.3 & 85.2 & 84.9 & 79.9 & 1.51 & 1.73 & 1.41 & 34.9 & 37.2 & 32.6 \\
\hline & FPRD & 87.7 & 82.8 & 84.9 & 83.0 & 85.5 & 81.9 & 1.38 & 1.57 & 1.28 & 33.1 & 33.9 & 30.5 \\
\hline & CI & 86.1 & 87.0 & 83.3 & 77.4 & 85.8 & 76.9 & 1.32 & 1.41 & 1.29 & 30.4 & 29.3 & 29.5 \\
\hline
\end{tabular}

On the other hand, under applied water amount of $\left(\mathrm{Q}_{3}\right)$, the control treatment recorded the lowest value of water application efficiency (49.5\%) compared with other treatments. Meanwhile under furrow slope of $0.05 \%$, the FPRD achieved the highest value (73.9\%) compared with APRD and CI treatments. While, under furrow slope of $0.1 \%$, the FPRD resulted the highest value $(81.9 \%)$ compared with APRD and CI treatments. For water distribution efficiency, under applied water amount of $\mathrm{Q}_{1}$, the FPRD treatment recorded the highest value under furrow slope of $0.05 \% 89.4 \%$, while under furrow slope of $0.1 \%$ APRD achieved highest value $89.7 \%$, also with applied water amount of $\mathrm{Q}_{2}$, the FPRD treatment recorded the highest value under furrow slope of $0.05 \%$ were $89.7 \%$, while under furrow slope of $0.1 \%$, the APRD treatment achieved the highest value $90.4 \%$. Meanwhile with applied water amount of $\mathrm{Q}_{3}$, the APRD treatment recorded the highest value under slopes of $0.05 \%$ and $0.1 \%$ were $89.8 \%$ and $89.3 \%$, respectively. The value of water use efficiency was the greatest value under the APRD treatment $\left(1.53 \mathrm{~kg} \mathrm{~m}^{-3}\right.$ and $1.73 \mathrm{~kg} \mathrm{~m}^{-3}$ ) compared with FPRD, CI and control irrigation. The results indicated that, the APRD treatment achieved the highest value of water saving in case of water cutting was occurred when irrigation water reached $5 \mathrm{~m}$ before the end of furrow length $\left(\mathrm{Q}_{2}\right)$, where the highest value under furrow slopes of $0.05 \%$ and $0.1 \%$ were $30.02 \%$ and $37.16 \%$, respectively.

\section{CONCOLUSION}

Water advance time was decreased by increasing furrow slope, but water recession time and irrigation depth were increased by increasing furrow slope. The highest value of corn yield was occurred under the PRD 
treatment where water cutting was occurred when irrigation water reached to the end of furrow length $\left(\mathrm{Q}_{1}\right)$, the APRD treatment achieved high value of corn yield (6.97 $\mathrm{Mg} \mathrm{ha}^{-1}$ ) under furrow slope of $0.05 \%$, and $(7.09 \mathrm{Mg}$ $\mathrm{ha}^{-1}$ ) under furrow slope of $0.1 \%$ compared with $\mathrm{CI}$ and control irrigation. Meanwhile, when the water cutting was occurred when irrigation water reached to the end of furrow with 5 minutes storage $\left(\mathrm{Q}_{3}\right)$, the APRD treatment recorded the highest value of corn yield under furrow slope of $0.05 \%$, and under furrow slope of $0.1 \%$ (7.71 and $7.85 \mathrm{mg} \mathrm{ha}^{-1}$, respectively).The value of water use efficiency was the greatest under the APRD treatment $\left(1.53 \mathrm{~kg} \mathrm{~m}^{-3}\right.$ and $\left.1.73 \mathrm{~kg} \mathrm{~m}^{-3}\right)$ compared with FPRD, CI and control irrigation treatments. The results indicated that the APRD treatment achieved the highest value of water saving in case of water cutting was occurred when irrigation water reached $5 \mathrm{~m}$ before the end of furrow length $\left(\mathrm{Q}_{2}\right)$, where the highest value under furrow slopes of $0.05 \%$ and $0.1 \%$ were $30.02 \%$ and $37.16 \%$, respectively.

\section{REFERANCES}

Abd El-Rahman, A. G. (1985). A study of efficiency of border irrigation.MSc. Thesis. Agric.Eng. Dept. Cairo Univ.

Abdel-Rahman M. E. (2010).Design of self-compensating nozzle for gated irrigation pipe.Unpublished Ph. Dep.Of Agri. Eng. Fac.Of Agri. Ain Shams Uni.

Amer A. M. and K. H., Amer (2010).Surface irrigation management in relation to water infiltration and distribution in soils. Soil \& Water Res., 5, (3) p.: 75-87.

Black,C.A, D.D. Evans, J.L. White, L.E. Ensminger and F.E. Clark (1965).Method of soil analysis (part 1).Amer.Soc.Agron.Inc., Madison, Wisconsin, USA. PP: $552-264$

Brouwer, C. A. Goffeau and M. Heibloem (1985).“Irrigation water management" Training Manual No. 1- Introduction. FAO -Food and agriculture organization of the united nation. Chapter 5. 
Casillas,G. (1978).Soil water engineering laboratory manual. Colorado State Univ., Dep. Of Agr.And Chem. Eng. Fort Collins, Colorado 805: 1-198.

Consoli.S., F., Stagno, D., Vanella J., Boaga, G., Cassiani, and G., Roccuzzo. (2017).Partial root-zone drying irrigation in orange orchards: Effects on water use and crop production characteristics Europ. J. Agronomy 82 (2017) 190-202.

El Tantawy, M.T, A.F El Sharkawy, M.N.Abo El Nour (2006).Effectof laser land leveling and width between furrows on water use efficiency and yield of soybean crop.Misr J. Ag. Eng., 23(1): $108-121$

El-Shafie, A.F., M.A. Osama, M.M. Hussein, A.M. El-Gindy, and R. Ragab, (2017).Predicting soil moisture distribution, dry matter, water productivity and potato yield under a Trailing Perforated Pipe irrigation system: SALTMED model application using field experimental data. Agricultural Water Management 184: 221-233.

Han, Y., and S. Kang (2002). Preliminary study on effects of roots divided alternate irrigation on nutrient uptake by maize. Transactions of the CSAE, 18(1):57-59.

James, G. L. (1988).Principles of farm irrigation system design. John Wiley and Sons, Inc.: 848. (85-105): 543pp

Lekakis E.H., P.E. Georgiou, A. Pavlatou-Ve and V.Z. Antonopoulos (2011).Effects of fixed partial root-zone drying irrigation and soil texture on water and solute dynamics in calcareous soils and corn yield.Agricultural Water Management 101: 71- 80.

Mahmoud S. Hashem, Tarek Zin El-Abedin, and M. Hussein Al-Ghobari (2019).Rational water use by applying regulated deficit and partial root-zone drying irrigation techniques in tomato under arid conditions.Chilean Journal of Agricultural Research 79(1).

Michael, A. M, (1978).“Irrigation theory and practice" $1{ }^{\text {st }}$ Edition, New Delhi, pp. 446-603. 
Osama A. M. A, and S. H. M. Ahmed (2015). Performance evaluation of gated pipes technique for improving surface irrigation efficiency in maize hybrids. Agricultural Sciences, 6, 550-570.

Wang.Z, F. Liu, S. Kang and C.R. Jensen (2012)Alternate partial rootzone drying irrigation improves nitrogen nutrition in maize (Zea mays L.) leaves. Environmental and Experimental Botany 75: 36-40.

Waseem A. G. (2017). Water scarcity in Egypt: causes and consequences. IIOAB Journal Vol. 8(4): 40-47.

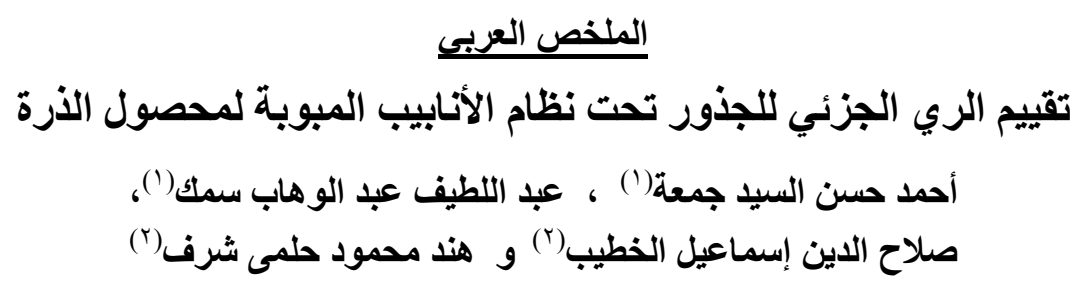

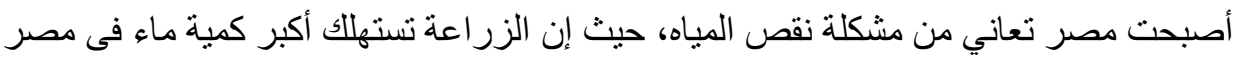

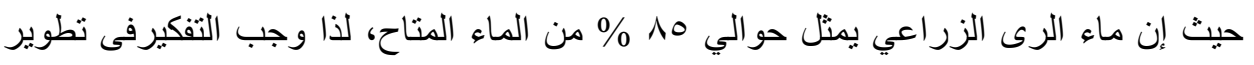

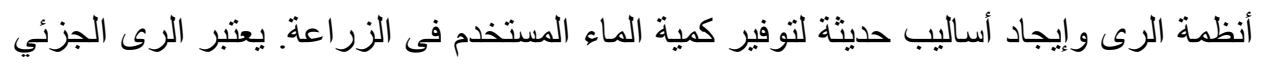

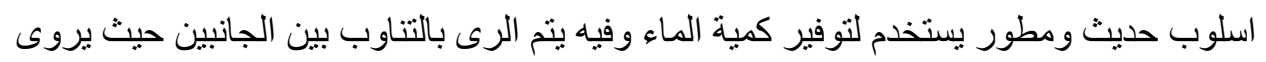

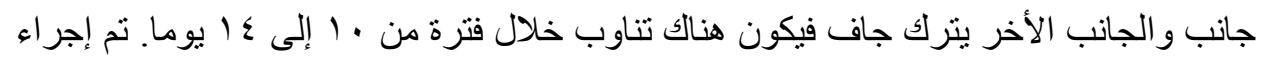

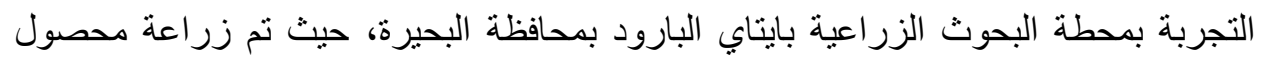

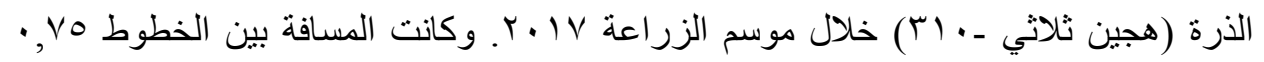

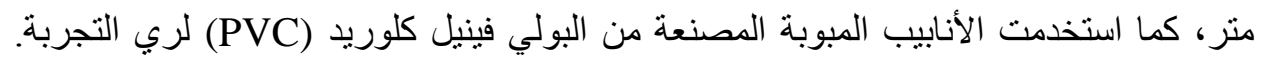
حيث كانت معاملات الدر اسة في التجربة كالاتي:

تسوية سطح التربة بالليزر باستخدام ميلين مختلفين لسطح التربة وهما هاتئ ه,. $\%$

أنظمة الرى وهي الرى الجزئي (التبادلي والثابت) والري التقليدي بالميول ومقارنة هذه الأنظمة بالري التقليدي بدون ميول و المستخدم مع معظم المز الري وارين.

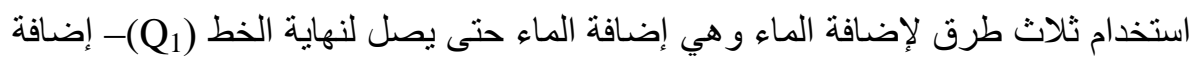

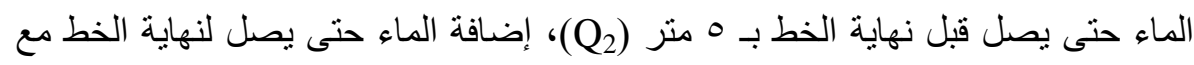

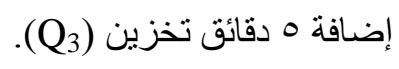

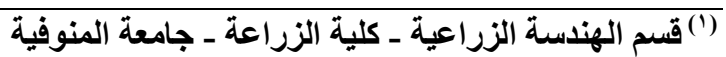

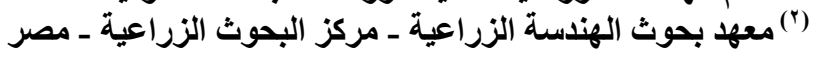


وكاتت النتائج المتحصل عليهالاتي:

ا. . حقق الرى الجزئي التبادلي باستخدام التسوية بالليزر تحت نظام الأنابيب المبوبة أفضل التبل

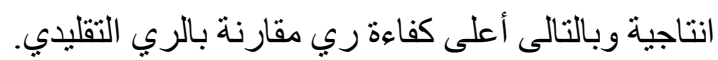

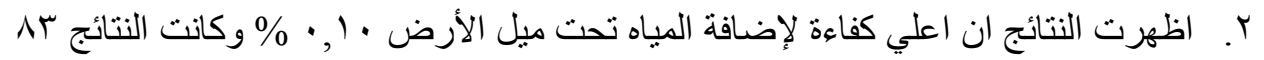

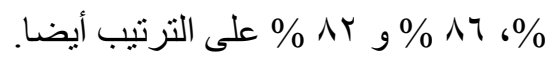

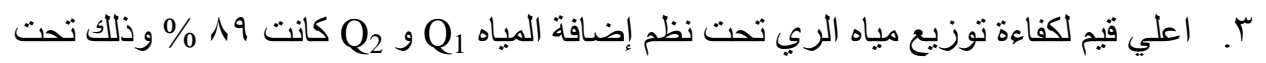

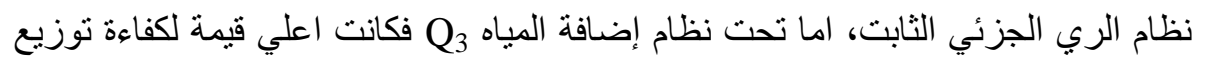
مياه الري •9 \% وذلك تحت نظام الري الجزئي التبادلي عند ميل سطح التربة مقداره $\% \cdot 0$ ع. تحت ميل سطح التربة يعادل • 1, \% \% كانت كفاءة توزيع مياه الري الأعلى تحت نظام

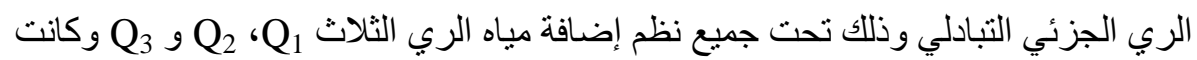
$\% 9$.

•. تحققت أعلي قيمة لكفاءة استخدام مياه الري في حالة معاملة الري الجزئي التبادلي مقارنة

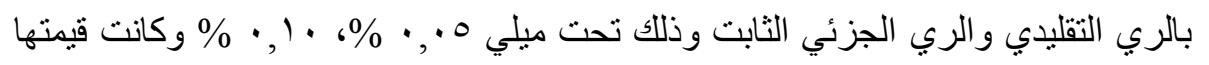

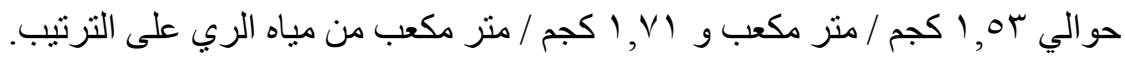

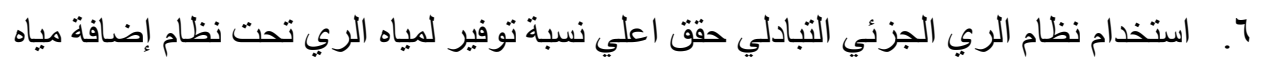

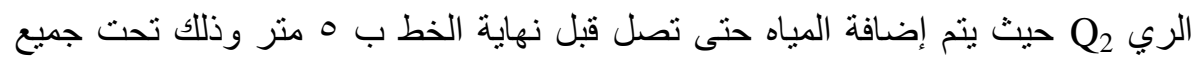

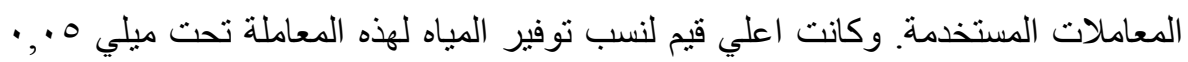

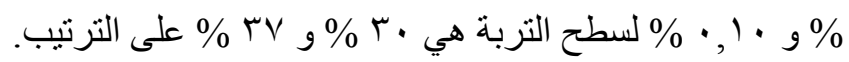

